\title{
Orbital controls on Namib Desert hydroclimate over the past 50,000 years
}

\author{
Brian M. Chase ${ }^{*}$, Eva M. Niedermeyer ${ }^{2}$, Arnoud Boom³ ${ }^{3}$, Andrew S. Carr ${ }^{3}$, Manuel Chevalier ${ }^{4}$, Feng He $\mathrm{H}^{5,6}$, \\ Michael E. Meadows ${ }^{7,8}$, Neil Ogle ${ }^{9}$, and Paula J. Reimer ${ }^{9}$ \\ ${ }^{1}$ Institut des Sciences de l'Evolution-Montpellier (ISEM), Université Montpellier, Centre National de la Recherche Scientifique \\ (CNRS), EPHE, IRD, Bâtiment 22, CC061, Place Eugène Bataillon, 34095 Montpellier, France \\ ${ }^{2}$ Senckenberg Biodiversity and Climate Research Centre (BiK-F), Senckenberg Gesellschaft für Naturforschung, \\ Senckenberganlage 25, D-60325 Frankfurt am Main, Germany \\ ${ }^{3}$ School of Geography, Geology and the Environment, University of Leicester, Leicester LE1 7RH, UK \\ ${ }^{4}$ Institute of Earth Surface Dynamics, Geopolis, University of Lausanne, Quartier UNIL-Mouline, Bâtiment Géopolis, CH-1015 \\ Lausanne, Switzerland \\ ${ }^{5}$ Center for Climatic Research, Nelson Institute for Environmental Studies, University of Wisconsin-Madison, Madison, Wisconsin \\ 53706, USA \\ ${ }^{6}$ College of Earth, Ocean, and Atmospheric Sciences, Oregon State University, Corvallis, Oregon 97331, USA \\ 'Department of Environmental and Geographical Science, University of Cape Town, Private Bag X3, Rondebosch 7701, South Africa \\ ${ }^{8}$ School of Geographical Sciences, East China Normal University, Shanghai 200241, People's Republic of China \\ ${ }^{9}$ School of Natural and Built Environment, Queen's University Belfast, Belfast BT7 1NN, Northern Ireland, UK
}

\begin{abstract}
Despite being one of the world's oldest deserts, and the subject of decades of research, evidence of past climate change in the Namib Desert is extremely limited. As such, there is significant debate regarding the nature and drivers of climate change in the low-latitude drylands of southwestern Africa. Here we present data from stratified accumulations of rock hyrax urine that provide the first continuous highresolution terrestrial climate record for the Namib Desert spanning the past 50,000 yr. These data, spanning multiple sites, show remarkably coherent variability that is clearly linked to orbital cycles and the evolution and perturbation of global boundary conditions. Contrary to some previous predictions of southwestern African climate change, we show that orbital-scale cycles of hydroclimatic variability in the Namib Desert region are in phase with those of the northern tropics, with increased local summer insolation coinciding with periods of increased aridity. Supported by climate model simulations, our analyses link this to variations in position and intensity of atmospheric pressure cells modulated by hemispheric and land-sea temperature gradients. We conclude that hydroclimatic variability at orbital time scales is driven by the combined influence of direct low-latitude insolation forcing and the influence of remote controls on the South Atlantic anticyclone, with attendant impacts on upwelling and sea-surface temperature variations.
\end{abstract}

\section{INTRODUCTION}

Past climate change at low latitudes in Africa is generally considered to be driven at orbital time scales by precessional variations in summer insolation (Collins et al., 2014; Kutzbach and Street-Perrott, 1985; Partridge et al., 1997), which affect the position and extent of the tropical African

*E-mail: brian.chase@umontpellier.fr rain belt (Partridge et al., 1997; Schefuß et al., 2011). In the northern and eastern African tropics, the influence of direct orbital forcing is well documented (Chevalier and Chase, 2015; Kutzbach and Street-Perrott, 1985; Partridge et al., 1997; Schefuß et al., 2011; Shanahan et al., 2015; Tierney et al., 2017; Tierney et al., 2008). In southwestern Africa (defined here as between $\sim 17^{\circ} \mathrm{S}$ and $30^{\circ} \mathrm{S}$, and extending eastward from the coast to $\sim 20^{\circ} \mathrm{E}$ ), where the influence of the South Atlantic anticyclone (SAA) and Benguela upwelling system play a significant role in driving regional aridity, the influence of orbital forcing is unclear (Chase et al., 2009; Collins et al., 2014; Lim et al., 2016). Here, low precipitation and strongly seasonal rainfall regimes have restricted the development of lakes and wetlands that could provide longer-term records of climate change. Long marine sediment records from the adjacent southeast Atlantic have been interpreted as indicating a strong positive relationship between summer insolation and precipitation in southwestern Africa (Collins et al., 2014) and across the wider subcontinent (Daniau et al., 2013). These findings, however, contrast with interpretations based on the limited terrestrial paleoenvironmental evidence from the Namib Desert (Fig. 1; Chase et al., 2010; Lim et al., 2016; Scott et al., 2004), and, as a result, there is no clear understanding of the nature of orbital-scale climate change and its underlying drivers in one of the world's most arid regions.

\section{MATERIALS AND METHODS}

To study past climate change in the Namib Desert, we have employed a unique paleoenvironmental archive: rock hyrax middens, the stratified accumulations of the petrified urine (hyraceum) of the rock hyrax (Procavia capensis). From these, we have derived a 50,000 yr terrestrial record of paleoclimate for southwestern Africa. Optimally preserved in dryland environments, hyrax middens provide unprecedentedly detailed hydroclimate evidence in their stable isotope records (Chase et al., 2015a,

CITATION: Chase, B.M., et al., 2019, Orbital controls on Namib Desert hydroclimate over the past 50,000 years: Geology, v. 47, p. 867-871, https://doi.org $/ 10.1130 / \mathrm{G} 46334.1$ 

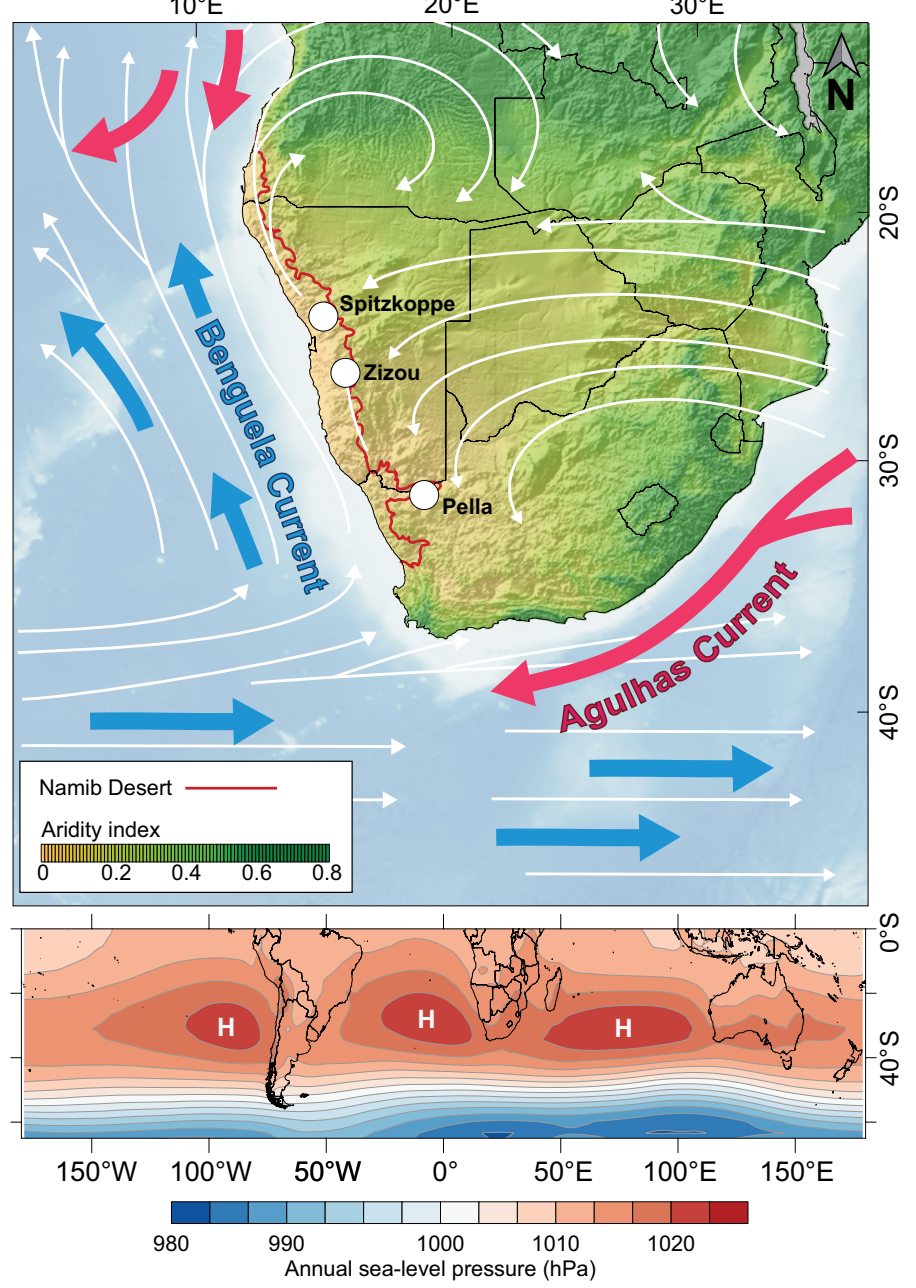

Figure 1. Modern hydroclimate and dominant circulation patterns of southern Africa. Rock hyrax midden sites at Spitzkoppe, Zizou, and Pella and limits of Namib Desert are indicated. Aridity index shown is that of Trabucco and Zomer (2009). Major ocean currents are indicated with bold arrows, and austral summer atmospheric circulation is indicated in white. Below: Distribution of major Southern Hemisphere high-pressure cells (H) (Collins et al., 2006).

2017, 2009, 2012). For this study, we consider three sites (Spitzkoppe: $15.20^{\circ} \mathrm{E}, 21.83^{\circ} \mathrm{S}$; Zizou: $15.97^{\circ} \mathrm{E}, 24.07^{\circ} \mathrm{S}$; Pella: $\left.19.14^{\circ} \mathrm{E}, 29.00^{\circ} \mathrm{S}\right)$ along a $900 \mathrm{~km}$ north-south transect of the Namib Desert (Fig. 1). Situated along the steep zonal hydroclimate gradient that forms a continuum from the arid to hyperarid Namib Desert in the west to the semiarid to dry subhumid environments to the east (Fig. 1), the sites were selected to assess climate change trends and events at a regional scale. Combined, eight middens from the three sites comprise a total of $208 \mathrm{~cm}$ of hyraceum accumulation, from which 1792 samples were analyzed for their stable nitrogen isotope composition $\left(\delta^{15} \mathrm{~N}\right)$. To achieve a more comprehensive understanding of regional hydroclimates, plant leaf wax $n$-alkanes were also extracted from the Spitzkoppe middens (93 samples spanning 32,500 yr) and analyzed for their hydrogen isotope composition $(\delta \mathrm{D})$. A chronology was established with $86{ }^{14} \mathrm{C}$ accelerator mass spectrometry ages from the hyraceum to build a composite sequence (Fig. 2; Figs. DR1 and DR2 in the GSA Data Repository $^{1}$ ). For details on these methods, see the Data Repository.

${ }^{1}$ GSA Data Repository item 2019314, the hyraceum $\delta^{15} \mathrm{~N}$, leaf wax $\delta \mathrm{D}$, and radiocarbon and sampling data that support the findings of this study, is available online at http://www.geosociety.org/datarepository/2019/, or on request from editing@geosociety.org.
Over the past 50,000 yr, significant variability (13.5\%o) is apparent in the hyraceum $\delta^{15} \mathrm{~N}$ values (Figs. DR1 and DR2). Despite the spatial range of the sites and the differences in accumulation rates, strong orbital-scale similarities are apparent between the trends in the records obtained (Figs. DR2 and DR3), and a regional composite was created using Gaussian kernel smoothing (Rehfeld et al., 2011) on the combined data sets (Fig. DR2).

Hyraceum $\delta^{15} \mathrm{~N}$ has been shown-through observation of modern middens and plants (Carr et al., 2016; Murphy and Bowman, 2006), as well as comparison with independent records and other proxies obtained from the same midden samples - to reflect environmental water availability, with higher $\delta^{15} \mathrm{~N}$ values occurring during more arid periods (Chase et al., $2015 \mathrm{a}, 2015 \mathrm{~b}, 2009)$. At low latitudes, $\delta \mathrm{D}$ variability is often predominantly controlled by precipitation amount and/or intensity (Collins et al., 2014; Garcin et al., 2012; Niedermeyer et al., 2016), consistent with the similarities between the $\delta \mathrm{D}_{\text {wax }}$ and $\delta^{15} \mathrm{~N}$ records presented here (Fig. 2) (for a fuller discussion, see the Data Repository).

\section{DISCUSSION}

Overall, our $\delta^{15} \mathrm{~N}$ record indicates that the last glacial period was generally more humid than the Holocene (Fig. 2). We consider temperature to be an important factor in defining this trend, with lower temperatures during the last glacial period limiting potential evapotranspiration and increasing water availability (Chevalier and Chase, 2016; Lim et al., 2016). Orbital-scale variability within and across the Holocene and Late Pleistocene in both the $\delta^{15} \mathrm{~N}$ and $\delta \mathrm{D}$ records conforms to precessional cycles, particularly during the last 36,000 yr (Fig. 2). Our composite record indicates that humidity in the Namib Desert region is generally negatively related to summer insolation. This contrasts with an inferred positive relationship between summer insolation and southern African precipitation (through the invigoration of tropical atmospheric circulation systems) from records obtained from marine archives from off the Namibian coast (Collins et al., 2014; Daniau et al., 2013). Comparing our results with climate model simulations (He et al., 2013) (Fig. 3) and evidence for intensifications of the SAA from wind and upwelling proxies (Fig. 2), we conclude that this cycle of variability is determined by two interrelated factors. The first is the inverse influence of high-northernlatitude summer insolation. Austral summer insolation maxima correlate with boreal summer insolation minima, which induces phases of global cooling, increasing latitudinal intra-hemispheric temperature gradients (Rind, 1998) and intensifying the SAA and related Benguela upwelling (Farmer et al., 2005; Little et al., 1997b; Pichevin et al., 2005; Stuut et al., 2002). This serves to limit regional atmospheric convection, block the incursion of moisture-bearing systems, and promote the advection of dry air eastward. The second is the influence of austral summer insolation on land-sea temperature and pressure gradients in southwestern Africa (Fig. 3 ). While global temperatures cool during periods of low boreal summer insolation, coeval increases in austral summer insolation raise summertime continental temperatures and enhance the land-sea pressure gradient, further increasing southerly air flow and augmenting coastal upwelling (Fig. 3). This combined influence of high- and low-latitude precessional forcing results in interhemispheric synchrony in orbital-scale patterns of climate change between the Namib Desert and the northern and eastern African tropics across the past 50,000 yr (Fig. 2).

The apparent contradiction between the records from marine (Collins et al., 2014; Daniau et al., 2013) and terrestrial archives from the region (compare Figs. 2B, 2C, and 2G) may reflect either (1) regional differentiation of climate signals, with marine records being predominantly influenced by sediment sourced in central southern Africa, as suggested by Collins et al. (2014) and Daniau et al. (2013), or (2) the role of eolian transport in determining the distinct patterns of variability in the marine records. As a significant vector for the deposition of terrestrial components in marine records (Dupont and Wyputta, 2003; Stuut et al., 2002), the extent and strength of the SAA has the potential to significantly change 
Figure 2. Records of environmental variability over the past 50,000 calibrated yr B.P. Holocene, last glacial-interglacial transition, and glacial periods are indicated with red, purple, and blue shading, respectively.Timing of the Last Glacial Maximum (LGM) is indicated, as are Heinrich stadials (HS) $\mathbf{1 - 5}$, which are more darkly shaded. For comparison or combination, some records have been normalized (norm.) using standard scores. (A) Cycles of boreal $\left(65^{\circ} \mathrm{N}\right)$ and austral $\left(25^{\circ} \mathrm{S}\right)$ insolation. JJA-June, July, August; DJF-December, January, February. (B) Composite $\delta^{15} \mathrm{~N}$ record from the Namib Desert (southwestern Africa) rock hyrax middens, with white zone indicating uncertainties associated with the creation of the regional composite record using Gaussian kernel smoothing (see the Data Repository [see footnote 1]; Rehfeld et al., 2011). ( C) Leaf wax $\delta D$ record from the Spitzkoppe rock hyrax midden (VSMOW-Vienna standard mean ocean water). (D,E) Namib Desert paleotemperature estimates from noble gases from the Stampriet aquifer (Stute and Talma, 1998) and a pollen-based temperature index (values in uncalibrated degrees Celsius) from the Pella rock hyrax midden (Lim et al., 2016). (F) Composite record for wind strength in the Benguela upwelling region, derived from sediment and foraminifera records (Farmer et al., 2005; Little et al., 1997a; Pichevin et al., 2005; Stuut et al., 2002). (G) Leaf wax $\delta D$ record from Namibian coastal marine core MD08-3167 (drilled during IMAGES cruise MD167/RETRO; Collins et al., 2014). (H) Leaf wax $\delta D$ record from Lake Tanganyika, East Africa (Tierney et al., 2008). (I) Leaf wax $\delta \mathrm{D}$ record from marine core GeoB 6518-1 (drilled during RV Meteor Cruise M47/3; Schefuß et al., 2005).( J) Leaf wax $\delta \mathrm{D}$ record from Lake Barombi, Cameroon (Garcin et al., 2018). (K) Leaf wax $\delta D$ record from Lake Bosumtwi, Ghana (Shanahan et al., 2015). Records of hydroclimate have been oriented with the y-axis indicating increases or decreases in humidity and/or precipitation.

the source area of these components. This is implied by the inclusion of pollen from increasingly remote sources during periods of intensified upwelling (Lim et al., 2016; Shi et al., 2001). Regional climate gradients are such that any expansion of the source area away from the arid continental margin would promote the inclusion of material from relatively more humid areas (Fig. 1). Thus, inferred positive correlations between precipitation and regional summer insolation may reflect the response of regional wind fields to orbital forcing rather than hydroclimatic conditions in the Namib Desert itself (Fig. 2).

During the Holocene, the influence of Northern Hemisphere ice sheets and ice rafting events (Chase et al., 2015a) on the position of the African rain belt (apparent in the midden record as the discrete humid episodes during Heinrich stadials 1-3; Fig. 2; see the Data Repository, and Fig. DR2 therein) diminished. Direct insolation forcing became the dominant control on multimillennial variability of precipitation in the eastern tropics of southern Africa, resulting in a progressive increase in summer rainfall (Chevalier and Chase, 2015; Schefuß et al., 2011) (Fig. 2). In contrast, conditions in the Namib Desert are characterized by progressive aridification (with the late Holocene being the driest period of the last 50,000 yr). This is consistent with patterns of change observed in the western (Collins et al., 2010; Garcin et al., 2018; Schefuß et al., 2005; Shanahan et al., 2015; Weldeab et al., 2007) and northern (Stager et al., 2003; Tierney et al., 2017) tropics. Similar to the dynamics described for the Late Pleistocene, model simulations indicate that orbital-scale hydroclimatic variability during the Holocene was determined by the combined influences of reduced highnorthern-latitude insolation and increased southern low-latitude summer insolation (Fig. 3). This has broader implications: from the early Holocene Northern Hemisphere summer insolation maximum, substantial cooling is observed in both the northern (Sachs, 2007), eastern equatorial (Weldeab et al., 2007), and southeastern Atlantic (Farmer et al., 2005), resulting in a progressive aridification of the whole western tropical margin, from the Namib Desert through the Gulf of Guinea (Garcin et al., 2018; Schefuß et al., 2005; Shanahan et al., 2015; Weldeab et al., 2007). In southwestern Africa, the impact was intensified by insolation-driven warming of the continental interior, which enhanced the land-sea temperature gradient,

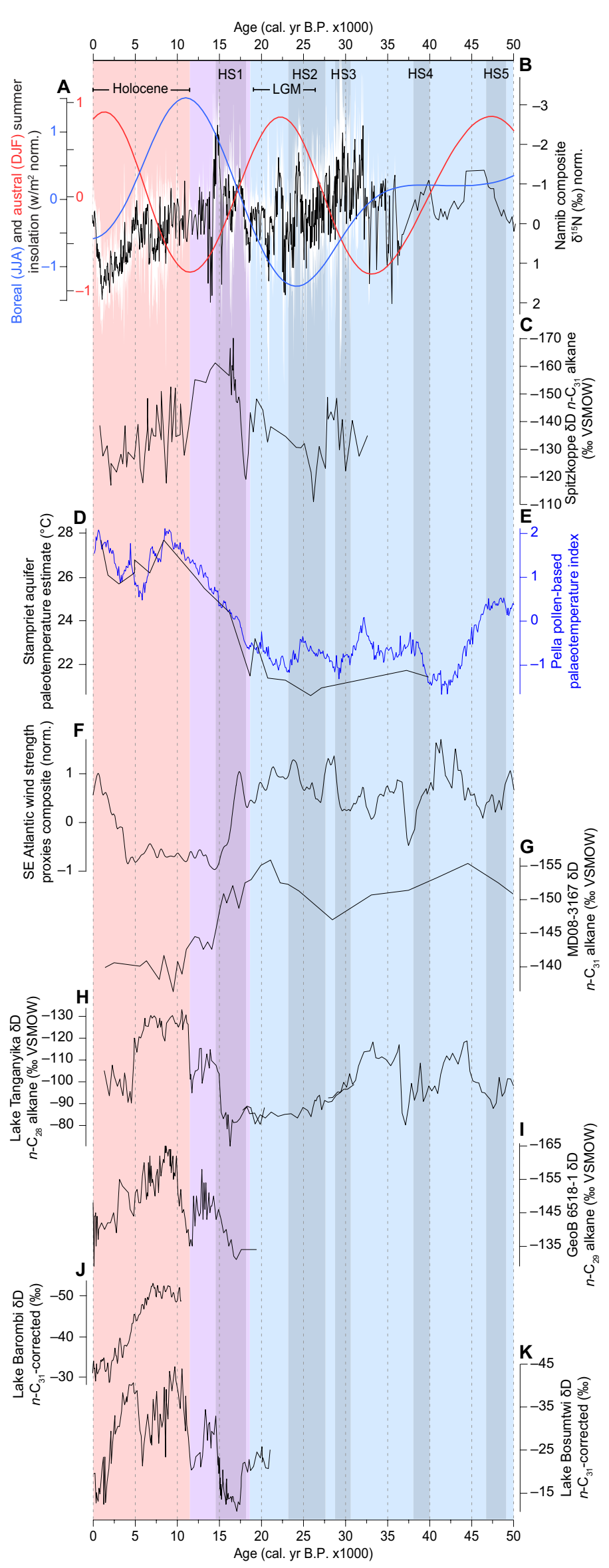



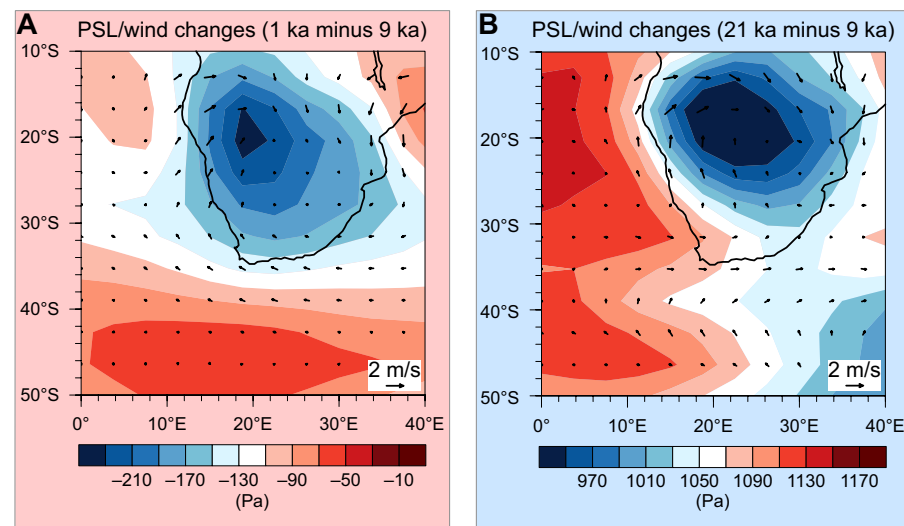

Precip./wind changes ( 1 ka minus 9 ka)

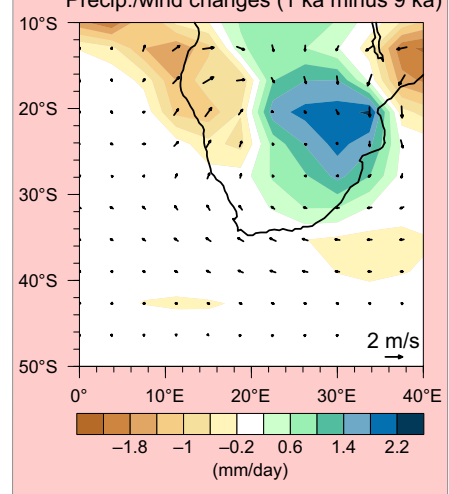

Precip./wind changes (21 ka minus $9 \mathrm{ka}$ )
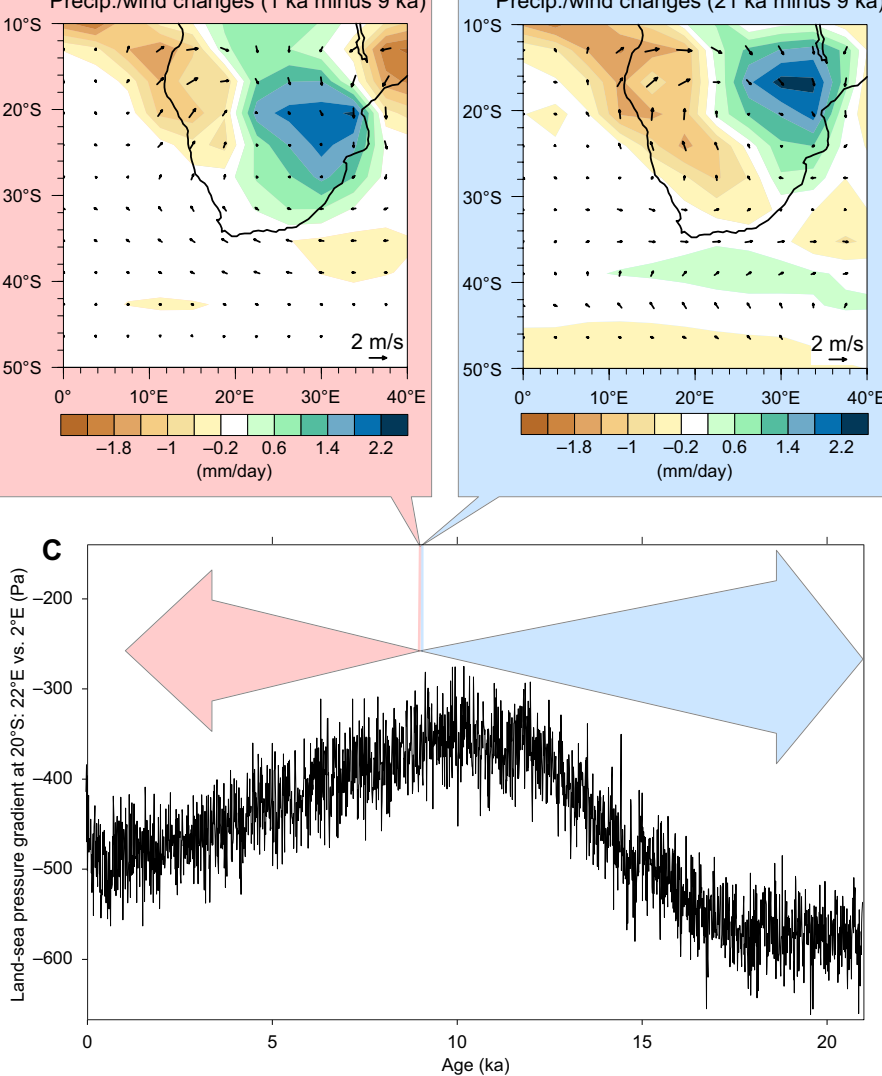

Figure 3. Orbital-scale dynamics determining phasing of Namib Desert hydroclimates. (A,B) TraCE21 ka (Simulation of Transient Climate Evolution over the last 21,000 years; http://www.cgd.ucar.edu/ccr /TraCE/) simulations (He et al., 2013; Liu et al., 2009) of sea-level pressure (PSL), precipitation, and wind-field changes between late and early Holocene (A; 1 ka minus 9 ka in red) and between Last Glacial Maximum and early Holocene (B; 21 ka minus 9 ka in blue). (C) TraCE21 ka simulation (He et al., 2013; Liu et al., 2009) of evolution of the strength of the land-sea pressure gradient between $22^{\circ} \mathrm{E}$ and $2^{\circ} \mathrm{E}$ from the Last Glacial Maximum to present day (arrows indicate direction of anomalies plotted in A and B, from periods of lower (9 ka) to higher (1 ka and $21 \mathrm{ka}$ ) sea-level pressure).

resulting in stronger coastal upwelling (Fig. 3). Thus, this mechanism is shown to influence southwestern African climate under both glacial and interglacial boundary conditions.

Our results show that low-latitude direct insolation forcing does not operate alone to produce a positive relationship between summer insolation and precipitation. Rather, the resulting low pressure that develops over the subcontinent reinforces the development of a strong east-west dipole. Enhanced tropical northerly flow increases precipitation over southeast- ern Africa, but coeval intensification of the South Atlantic anticyclone and Benguela upwelling system result in the transport of dry air across southwestern Africa, resulting in markedly drier conditions. Contrary to previous postulations, long-term hydroclimatic variability in the Namib Desert is in phase with and strongly linked to high-latitude Northern Hemisphere controls. These results provide a new benchmark for the evaluation of records obtained from southwestern Africa, offering a new perspective on past climate dynamics in the Southern Hemisphere low latitudes and a novel model for understanding past climate dynamics in the southern subtropics.

\section{ACKNOWLEDGMENTS}

The research leading to these results has received funding from the European Research Council (ERC) under the European Union's Seventh Framework Programme (FP7/2007-2013), ERC Starting Grant "HYRAX", grant agreement no. 258657. F. He was supported by the U.S. National Science Foundation (NSF grants AGS-1502990, AGS- 1602771); the Climate, People, and the Environment Program of the Nelson Institute for Environmental Studies (Wisconsin, USA); and by the U.S. National Oceanic and Atmospheric Administration (NOAA) Climate and Global Change Postdoctoral Fellowship program, administered by the University Corporation for Atmospheric Research (UCAR). We would like to acknowledge high-performance computing support from Yellowstone (http://n2t .net/ark:/85065/d7wd3xhc) and Cheyenne (https://doi.org/10.5065/D6RX99HX) provided by NCAR's Computational and Information Systems Laboratory, sponsored by the U.S. National Science Foundation. This research used resources of the Oak Ridge Leadership Computing Facility at the Oak Ridge National Laboratory (Tennessee, USA), which is supported by the Office of Science of the U.S. Department of Energy under Contract No. DE-AC05-00OR22725. We also thank the three anonymous reviewers for their constructive comments.

\section{REFERENCES CITED}

Carr, A.S., Chase, B.M., Boom, A., and Medina-Sanchez, J., 2016, Stable isotope analyses of rock hyrax faecal pellets, hyraceum and associated vegetation in southern Africa: Implications for dietary ecology and palaeoenvironmental reconstructions: Journal of Arid Environments, v. 134, p. 33-48, https://doi .org/10.1016/j.jaridenv.2016.06.013.

Chase, B.M., Meadows, M.E., Scott, L., Thomas, D.S.G., Marais, E., Sealy, J., and Reimer, P.J., 2009, A record of rapid Holocene climate change preserved in hyrax middens from southwestern Africa: Geology, v. 37, p. 703-706, https:// doi.org/10.1130/G30053A.1.

Chase, B.M., Meadows, M.E., Carr, A.S., and Reimer, P.J., 2010, Evidence for progressive Holocene aridification in southern Africa recorded in Namibian hyrax middens: Implications for African Monsoon dynamics and the "African Humid Period": Quaternary Research, v. 74, p. 36-45, https://doi.org/10.1016 j.yqres.2010.04.006.

Chase, B.M., Scott, L., Meadows, M.E., Gil-Romera, G., Boom, A., Carr, A.S., Reimer, P.J., Truc, L., Valsecchi, V., and Quick, L.J., 2012, Rock hyrax middens: a palaeoenvironmental archive for southern African drylands: Quaternary Science Reviews, v. 56, p. 107-125, https://doi.org/10.1016/j.quascirev .2012.08.018.

Chase, B.M., Boom, A., Carr, A.S., Carré, M., Chevalier, M., Meadows, M.E., Pedro, J.B., Stager, J.C., and Reimer, P.J., 2015a, Evolving southwest African response to abrupt deglacial North Atlantic climate change events: Quaternary Science Reviews, v. 121, p. 132-136, https://doi.org/10.1016/j.quascirev .2015.05.023.

Chase, B.M., Lim, S., Chevalier, M., Boom, A., Carr, A.S., Meadows, M.E., and Reimer, P.J., 2015b, Influence of tropical easterlies in southern Africa's winter rainfall zone during the Holocene: Quaternary Science Reviews, v. 107, p. 138-148, https://doi.org/10.1016/j.quascirev.2014.10.011.

Chase, B.M., Chevalier, M., Boom, A., and Carr, A.S., 2017, The dynamic relationship between temperate and tropical circulation systems across South Africa since the last glacial maximum: Quaternary Science Reviews, v. 174, p. 54-62, https://doi.org/10.1016/j.quascirev.2017.08.011.

Chevalier, M., and Chase, B.M., 2015, Southeast African records reveal a coherent shift from high- to low-latitude forcing mechanisms along the east African margin across last glacial-interglacial transition: Quaternary Science Reviews, v. 125, p. 117-130, https://doi.org/10.1016/j.quascirev.2015.07.009.

Chevalier, M., and Chase, B.M., 2016, Determining the drivers of long-term aridity variability: A southern African case study: Journal of Quaternary Science, v. 31 , p. $143-151$, https://doi.org/10.1002/jqs.2850.

Collins, J.A., Schefuß, E., Govin, A., Mulitza, S., and Tiedemann, R., 2014, Insolation and glacial-interglacial control on southwestern African hydroclimate over the past 140,000 years: Earth and Planetary Science Letters, v. 398, p. 1-10, https://doi.org/10.1016/j.epsl.2014.04.034. 
Collins, J.A., et al., 2010, Interhemispheric symmetry of the tropical African rainbelt over the past 23,000 years: Nature Geoscience, v. 4, p. 42-45, https://doi .org/10.1038/ngeo1039.

Collins, W.D., et al., 2006, The Community Climate System Model version 3 (CCSM3): Journal of Climate, v. 19, p. 2122-2143, https://doi.org/10.1175 /JCLI3761.1.

Daniau, A.-L., Sánchez Goñi, M.F., Martinez, P., Urrego, D.H., Bout-Roumazeilles, V., Desprat, S., and Marlon, J.R., 2013, Orbital-scale climate forcing of grassland burning in southern Africa: Proceedings of the National Academy of Sciences of the United States of America, v. 110, p. 5069-5073, https://doi .org/10.1073/pnas.1214292110.

Dupont, L.M., and Wyputta, U., 2003, Reconstructing pathways of aeolian pollen transport to the marine sediments along the coastline of SW Africa: Quaternary Science Reviews, v. 22, p. 157-174, https://doi.org/10.1016/S0277 -3791(02)00032-X.

Farmer, E.C., deMenocal, P.B., and Marchitto, T.M., 2005, Holocene and deglacial ocean temperature variability in the Benguela upwelling region: Implications for low-latitude atmospheric circulation: Paleoceanography, v. 20, PA2018, https://doi.org/10.1029/2004PA001049.

Garcin, Y., Schwab, V.F., Gleixner, G., Kahmen, A., Todou, G., Séné, O., Onana, J.-M., Achoundong, G., and Sachse, D., 2012, Hydrogen isotope ratios of lacustrine sedimentary $n$-alkanes as proxies of tropical African hydrology: Insights from a calibration transect across Cameroon: Geochimica et Cosmochimica Acta, v. 79, p. 106-126, https://doi.org/10.1016/j.gca.2011.11.039.

Garcin, Y., et al., 2018, Early anthropogenic impact on Western Central African rainforests 2,600 y ago: Proceedings of the National Academy of Sciences of the United States of America, v. 115, p. 3261-3266, https://doi.org/10.1073 /pnas. 1715336115.

He, F., Shakun, J.D., Clark, P.U., Carlson, A.E., Liu, Z., Otto-Bliesner, B.L., and Kutzbach, J.E., 2013, Northern Hemisphere forcing of Southern Hemisphere climate during the last deglaciation: Nature, v. 494, p. 81-85, https://doi.org $/ 10.1038 /$ nature 11822 .

Kutzbach, J.E., and Street-Perrott, F.A., 1985, Milankovitch forcing of fluctuations in the level of tropical lakes from 18 to 0 kyr BP: Nature, v. 317, p. 130-134, https://doi.org/10.1038/317130a0.

Lim, S., Chase, B.M., Chevalier, M., and Reimer, P.J., 2016, 50,000 years of vegetation and climate change in the southern Namib Desert, Pella, South Africa: Palaeogeography, Palaeoclimatology, Palaeoecology, v. 451, p. 197-209, https://doi.org/10.1016/j.palaeo.2016.03.001.

Little, M.G., Schneider, R.R., Kroon, D., Price, B., Bickert, T., and Wefer, G., 1997a, Rapid palaeoceanographic changes in the Benguela Upwelling System for the last 160,000 years as indicated by abundances of planktonic foraminifera: Palaeogeography, Palaeoclimatology, Palaeoecology, v. 130, p. 135-161, https://doi.org/10.1016/S0031-0182(96)00136-8.

Little, M.G., Schneider, R.R., Kroon, D., Price, B., Summerhayes, C.P., and Segl, M., 1997b, Trade wind forcing of upwelling, seasonality, and Heinrich events as a response to sub-Milankovitch climate variability: Paleoceanography, v. 12, p. 568-576, https://doi.org/10.1029/97PA00823.

Liu, Z., et al., 2009, Transient simulation of last deglaciation with a new mechanism for Bølling-Allerød warming: Science, v. 325, p. 310-314, https://doi .org/10.1126/science. 1171041 .

Murphy, B.P., and Bowman, D.M.J.S., 2006, Kangaroo metabolism does not cause the relationship between bone collagen $\delta^{15} \mathrm{~N}$ and water availability: Functional Ecology, v. 20, p. 1062-1069, https://doi.org/10.1111/j.1365-2435 2006.01186.x.

Niedermeyer, E.M., Forrest, M., Beckmann, B., Sessions, A.L., Mulch, A., and Schefuß, E., 2016, The stable hydrogen isotopic composition of sedimentary plant waxes as quantitative proxy for rainfall in the West African Sahel: Geochimica et Cosmochimica Acta, v. 184, p. 55-70, https://doi.org/10.1016/j .gca.2016.03.034.

Partridge, T.C., deMenocal, P.B., Lorentz, S.A., Paiker, M.J., and Vogel, J.C., 1997, Orbital forcing of climate over South Africa: A 200,000-year rainfall record from the Pretoria Saltpan: Quaternary Science Reviews, v. 16, p. 1125-1133, https://doi.org/10.1016/S0277-3791(97)00005-X.

Pichevin, L., Cremer, M., Giraudeau, J., and Bertrand, P., 2005, A 190 kyr record of lithogenic grain-size on the Namibian slope: Forging a tight link between past wind-strength and coastal upwelling dynamics: Marine Geology, v. 218, p. 81-96, https://doi.org/10.1016/j.margeo.2005.04.003.

Rehfeld, K., Marwan, N., Heitzig, J., and Kurths, J., 2011, Comparison of correlation analysis techniques for irregularly sampled time series: Nonlinear Processes in Geophysics, v. 18, p. 389-404, https://doi.org/10.5194/npg-18-389-2011.

Rind, D., 1998, Latitudinal temperature gradients and climate change: Journal of Geophysical Research, v. 103, p. 5943-5971, https://doi.org/10.1029 197JD03649.

Sachs, J.P., 2007, Cooling of Northwest Atlantic slope waters during the Holocene: Geophysical Research Letters, v. 34, L03609, https://doi.org/10.1029 12006 GL028495.

Schefuß, E., Schouten, S., and Schneider, R.R., 2005, Climatic controls on central African hydrology during the past 20,000 years: Nature, v. 437, p. 1003-1006, https://doi.org/10.1038/nature03945.

Schefuß, E., Kuhlmann, H., Mollenhauer, G., Prange, M., and Pätzold, J., 2011, Forcing of wet phases in southeast Africa over the past 17,000 years: Nature, v. 480, p. 509-512, https://doi.org/10.1038/nature10685.

Scott, L., Marais, E., and Brook, G.A., 2004, Fossil hyrax dung and evidence of Late Pleistocene and Holocene vegetation types in the Namib Desert: Journal of Quaternary Science, v. 19, p. 829-832, https://doi.org/10.1002/jqs.870.

Shanahan, T.M., McKay, N.P., Hughen, K.A., Overpeck, J.T., Otto-Bliesner, B., Heil, C.W., King, J., Scholz, C.A., and Peck, J., 2015, The time-transgressive termination of the African Humid Period: Nature Geoscience, v. 8, p. 140-144, https://doi.org/10.1038/ngeo2329.

Shi, N., Schneider, R., Beug, H.-J., and Dupont, L.M., 2001, Southeast trade wind variations during the last $135 \mathrm{kyr}$ : Evidence from pollen spectra in eastern South Atlantic sediments: Earth and Planetary Science Letters, v. 187, p. 311321, https://doi.org/10.1016/S0012-821X(01)00267-9.

Stager, J.C., Cumming, B.F., and Meeker, L.D., 2003, A 10,000-year high-resolution diatom record from Pilkington Bay, Lake Victoria, East Africa: Quaternary Research, v. 59, p. 172-181, https://doi.org/10.1016/S0033-5894(03)00008-5.

Stute, M., and Talma, A.S., 1998, Glacial temperatures and moisture transport regimes reconstructed from noble gas and $\delta^{18} \mathrm{O}$, Stampriet aquifer, Namibia: Isotope Techniques in the Study of Past and Current Environmental Changes in the Hydrosphere and the Atmosphere: Vienna, Austria, International Atomic Energy Agency, v. SM-349/53, p. 307-318.

Stuut, J.-B.W., Prins, M.A., Schneider, R.R., Weltje, G.J., Jansen, J.H.F., and Postma, G., 2002, A 300-kyr record of aridity and wind strength in southwestern Africa: Inferences from grain-size distributions of sediments on Walvis Ridge, SE Atlantic: Marine Geology, v. 180, p. 221-233, https://doi.org/10 .1016/S0025-3227(01)00215-8.

Tierney, J.E., Russell, J.M., Huang, Y., Sinninghe Damsté, J.S., Hopmans, E.C., and Cohen, A.S., 2008, Northern Hemisphere controls on tropical southeast African climate during the past 60,000 years: Science, v. 322, p. 252-255, https://doi.org/10.1126/science.1160485.

Tierney, J.E., deMenocal, P.B., and Zander, P.D., 2017, A climatic context for the out-of-Africa migration: Geology, v. 45, p. 1023-1026, https://doi.org/10 .1130/G39457.1.

Trabucco, A., and Zomer, R.J., 2009, Global aridity index (Global-Aridity) and global potential evapo-transpiration (Global-PET) geospatial database: Consultative Group for International Agricultural Research-Consortium for Spatial Information (CGIAR-CSI) GeoPortal, http://www.csi.cgiar.org (accessed September 2017).

Weldeab, S., Lea, D.W., Schneider, R.R., and Andersen, N., 2007, 155,000 years of West African monsoon and ocean thermal evolution: Science, v. 316, p. $1303-$ 1307, https://doi.org/10.1126/science.1140461.

Printed in USA 